\title{
PERAN SEKRETARIAT DEWAN PERWAKILAN RAKYAT DAERAH DALAM MENUNJANG KINERJA ANGGOTA DEWAN PERWAKILAN RAKYAT DAERAH KABUPATEN KUANTAN SINGINGI
}

\author{
Rika Ramadhanti \\ Program Studi Administrasi Negara, Fakultas Ilmu Sosial, Universitas Islam Kuantan Singingi, Indonesia \\ rika.rasyidin@gmail.com
}

\begin{abstract}
Abstrak
Dewan Perwakilan Rakyat Daerah (DPRD) merupakan salah satu lembaga atau badan perwakilan rakyat di daerah. DPRD dalam melaksanakan tugasnya, mempunyai hak, wewenang dan kewajiban didalam mengemban tugasnya sebagai wakil rakyat. Pemberian hak-hak yang luas kepada DPRD merupakan suatu petunujuk bahwa demokratisasi pemerintahan daerah diharapkan makin menunjukkan bentuk yang lebih nyata. Untuk menunjang kinerja DPRD, sebagaimana diamanatkan Undang-Undang Nomor 23 Tahun 2014 tentang pemerintahan daerah yang kemudian dipertegas oleh Peraturan Pemerintah Nomor 18 Tahun 2016 Tentang Perangkat Daerah, bahwa sekretariat DPRD adalah perangkat daerah yang merupakan unsur pelayanan administrasi terhadap DPRD, yang meliputi penyelenggaraan kesekretariatan DPRD, penyelenggaraan administrasi keuangan DPRD, mendukung pelaksanaan tugas dan fungsi DPRD, serta penyediaan dan pengkoordinasian tenaga ahli yang diperlukan oleh DPRD.

Kata kunci: Peranan, Kinerja, Kuatan Singingi.
\end{abstract}

\begin{abstract}
Absract
The Regional People's Legislative Assembly (DPRD) is one of the institutions or representative bodies of the people in the region. DPRD in carrying out its duties, has the rights, authority and obligations in carrying out its duties as representatives of the people. The granting of broad rights to the DPRD is a sign that the democratization of regional government is expected to show more tangible forms. To support the performance of the DPRD, as mandated by Law Number 23 of 2014 concerning regional governance which was then confirmed by Government Regulation Number 18 of 2016 concerning Regional Devices, that the DPRD secretariat is a regional apparatus which is an element of administrative service to the DPRD, which includes the administration of DPRD secretariat, the administration of the DPRD's financial administration, supporting the implementation of the duties and functions of the DPRD, as well as the provision and coordination of experts needed by the DPRD. Keywords: Role, Performance, Kuatan Singingi.
\end{abstract}




\section{PENDAHULUAN}

Sebagaimana diatur dalam Undang-Undang Nomor 23 Tahun 2014 Tentang Pemerintahan Daerah, bahwa Dewan Perwakilan Rakyat Daerah (DPRD) dan Kepala Daerah memiliki kedudukan yang setara dan bersifat kemitraan. Dalam kedudukan kerja yang setara tersebut tidak hanya terkandung makna kesetaraan dalam hal otoritas tetapi semestinya juga setara dalam hal tanggung jawab dan kapasitas dalam memastikan proses pemerintahan dan pembangunan berjalan dengan baik. Posisi DPRD dalam pemerintahan daerah memegang tiga peranan penting yakni, legislasi, anggaran dan pengawasan. Legislasi adalah merancang kebijakan-kebijakan serta regulasi yang mendukung terciptanya pelayanan publik yang baik dan sesuai standar. Fungsi budgeting adalah memastikan bahwa anggaran dialokasikan sesuai dengan tepat sasaran, efisien baik dari segi jumlah maupun dari segi waktu. Sedangkan pengawasan adalah fungsi untuk memonitor dan mengevaluasi pelaksanaan peraturan daerah dan penggunaan anggaran.

Untuk mendukung pelaksanaan fungsi DPRD tersebut maka DPRD memiliki sekretariat DPRD. Sebagaimana diamanatkan Undang-undang Nomor 23 Tahun 2014 tentang Pemerintahan Daerah yang kemudian dipertegas dengan adanya Peraturan Pemerintah Nomor. 18 Tahun 2016 Tentang Perangkat Daerah, bahwa sekretariat DPRD adalah "perangkat daerah" yang merupakan unsur pelayanan administrasi terhadap DPRD, yang meliputi penyelenggaraan kesekretariatan DPRD, penyelenggaraan administrasi keuangan DPRD, mendukung pelaksanaan tugas dan fungsi DPRD, serta penyediaan dan pengkoordinasian tenaga ahli yang diperlukan oleh DPRD.

Sekretariat Dewan merupakan sebuah organisasi yang besar dan kompleks yang tidak memungkinkan para anggota dewan bekerja sendirian. Tentunya sudah menjadi syarat yang mutlak anggota dewan tersebut dibantu oleh pihak lain yang dalam hal ini adalah pegawai sekretariat dewan yang benar-benar memiliki kemampuan dan keahlian dalam bidang-bidang tertentu, dalam hal-hal yang bersifat teknis yang tidak dapat dijangkau oleh para wakil rakyat. Hal ini tentunya sangat diperlukan bagi anggota DPRD dalam menjalankan tugas dan fungsinya secara baik dan mencapai tujuan secara maksimal.

Keberadaan organisasi Sekretariat Dewan adalah merupakan bagian Integral dari pemerintah baik kabupaten ataupun kota yang keberadaannya merupakan bagian yang tidak terpisahkan apabila membicarakan kinerja DPRD. Karena dibagian Sekretariat dewan inilah, kebanyakan formulasi dan evaluasi maupun implementasi dari fungsi dan keberaadaan dewan 
tersebut dilaksanakan dan dikerjakan, atau dalam bahasa yang sederhana "dapur" kerja Dewan itu ada di Sekretariat Dewan dengan beberapa bagian yang merupakan alat kelengkapan organisasi. Maka berdasarkan tugas pokok dan fungsi dari sekretariat DPRD dituntut untuk memberikan pelayanan yang professional dan berkualitas untuk mendukung fungsi DPRD sebagai wakil rakyat yang menyerap aspirsi rakyat.

Melihat kedudukan, tugas dan fungsi sekretariat DPRD tersebut maka dapatlah dikatakan bahwa sekretariat DPRD mempunyai peranan yang sangat penting dan turut menentukan efektifitas pelaksanaan fungsi DPRD. Artinya bahwa efektifitas pelaksanaan tugas dan fungsi sekretariat DPRD dapat menentukan efektifitas pelaksanaan tugas dan fungsi DPRD. Oleh karena itu, untuk mewujudkan atau meningkatkan efektifitas DPRD maka sekretariat DPRD harus dapat berperan maksimal sesuai tugas dan fungsinya.

\section{TINJAUAN PUSTAKA}

\section{Konsep Administrasi}

Administrasi dalam arti luas mencakup keseluruhan proses aktivitas kerjasama sejumlah manusia didalam organisasi untuk mencapai satu atau sejumlah tujuan yang telah ditetapkan sebelumnya. Menurut Atmosudirdjo (dalam Zulkifli : 17 ) merupakan konsep administrasi adalah:

1. administrasi sebagai fungsi atau kegiatan (activity) adalah seperangkat kegitan-kegiatan yang tertentu dan terarah yang berlansung untuk memimpin serta mengendalikan suatu oraganisasi modern yang menjadi wahana suatu urusan atau usaha dan sekaligus apa yang berlangsung didalamnya.

2. Organisasi modern sebagai badan adalah organisasi yang mempunyai konstitusi dan statute yang tertentu sehingga jelas apa yang menjadi maksud (purpose) dan tujuan-tujuan (goals), usahanya, sumber pendanaanya (financial resours), serta langkah-langkah yang akan ditempuh untuk mencapai tujuan-tujuannya.

3. Setiap organisasi modern dikepalai (yang bertugas dan bertanggungjawab) dan dipimpin (yang menggerakkan secara terarah dan bertujuan) oleh administrator.

4. Administratir bisa perorangan bisa suatu dewan

5. Administrator menunaikan tugas, wewenang, kewajiban, dan tanggungjawabnya melalui apa yang disebut administrasi. 
Ungkapan Wiliam H. Newman (dalam Zulkifli 2005 :9 ) konsep administrasi dalam arti luas diartikan sebagai petunjuk bagi seseorang dalam memimpin dan mengontrol dari suatu kelompok atau individu untuk mencapai sebuah tujuan. Secara subsantasial dapat dilihat bahwa konsep administrasi merupakan bahwa :

1. Adminstasi dapat dipandang sebagai seni. Keberhasilan penerapannya memerlukan kiatkiat tertentu yang bersifat sangat situasional dan kondisonal. Administrasi sangat terikat kepada aspek kondisi, situasi, waktu dan tempat dimana dia dijalankan.

2. Didalam konsep administrasi terdapat unsure-unsur adanya dua orang atau lebih , adanya tujuan yang hendak dicapai, adanya tugas-tugas yang harus dilaksankaan, adanya perlengkapan dan peralatan untuk melaksanakan tugas, dan adanya pertimbangan yang rasionalitas dalam merumuskan dan menyediakan setiap unsure diatas.

3. Administrasi sebagai suatu proses kerjasama bukan merupakan konsep yang baru. Dia sudah ada dijalankan sejak manusia mengenal pradaban. Tetang keberadaan administrasi sebagai suatu proses tindakan tergambar pada ungkapan yang dikemukakan oleh Herbert A. Simon (dalam Siagian, 1986: 5 ) yaitu apabila orang yang bekerja bersama untuk menggulingkan sebuah atau yang tidak dapat digulingkan hanya oleh seorang diantara mereka, pada saat itu administrasi telah ada.

\section{Konsep Organisasi Manajemen}

Menurut Max Weber (Kencana 2006: 53) Organisasi itu tetap merupakan sebagai suatu lingkaran masyarakat yang harus membiasakan dirinya untuk patuh kepada perintahperintah pemimpinnya, di mana masing-msing mempunyai perhatian pribadi secara berkesinambungan dalam pengaturan kebijaksanaan, sebagai partisipasi mereka bersama dan hasil yang bermanfaat, dapat dilakukan pembagian pelatihan kerja dan fungsi (tugas) mereka masing-masing.

Pendapat lain mengenai organisasi disampaikan oleh Luther Gilick (Kencana : 52) dimana menurutnya organisasi adalah sebagai suatu alat saling berhubungan satua-satuan kerja yang memberikan mereka kepada orang-orang yang ditempatkan dalam struktur kewenangan. Jadi dengan demikian pekerjaan dapat dikoordinasikan oleh perintah atasan kepada para bawahan yang menjangkau dari puncak hingga kedasar dari seluruh badan usaha. Prinsip-prinsip organisasi yang dikemukakan Gulick adalah sebagai berikut :

- Penempatan secara tepatorang-orang pada stukrut organisasi 
- Pengakuan terhadap orang yang berada pada posisi puncak kepimpinan sebagai sumber dari otoritas atau wewenang.

- Memiliki kaitan dengan satuan perintah

- Penggunaan staf khusus dan staf umum

- Pembentukan departemenisasi berdasarkan pada tujuan, proses, orang dan tempat.

- Pendelegasian/pelimpahan dan pengunaan prinsip pengecualian

- Menempatkan tanggung jawab sepadan dengan wewenang

- Mempertimbangan cakupan pengawasan yang tepat.

\section{Pengertian Peranan}

Menurut Miftah Thoha (2012: 10) Peranan adalah suatu rangkaian yang teratur, yang ditimbulkan karena suatu jabatan tertentu, atau karena adanya suatu kantor yang mudah dikenal. Kepribadian seseorang barangkali juga amat mempengaruhi bagaimana peranan harus dijalankan. Peranan timbul karena seseorang memahami bahwa ia bekerja tidak sendirian. Mempunyai lingkungan, yang setiap diperlukan untuk berinteraksi. Lingkungan itu luas dan beraneka macam, dan masing-masing mempunyai lingkungan yang berlainan. Tetapi peranan harus dimainkan dan pada hakikatnya tidak ada perbedaan.

Menurut Mintzberg (dalam Miftah Thoha 2012: 21) ada tiga peranan yang dilakukan pemimpin dalam organisasi yakni :

1. Peranan antar pribadi (interpersonal role), dalam peranan antar pribadi, atasan harus bertindak sebagai tokoh, sebagai pemimpin dan sebagai penghubung agar organisasi yang dikelola berjalan lancar.

2. Peranan yang berhubungan dengan informasi (informational role), peranan interpersonal diatas meletakkan atasan pada posisi yang unik dalam halmendapatkan informasi.

3. Peran pengambilan keputusan (Decisional Role), dalam peranan ini atasan harus terlibat dalam sautu proses pembuatan strategi didalam organisasi yang dipimpinnya. Mintzberg (dalam Siswanto 2012: 21) berkesimpulan bahwa pembagian besar tugas atasan pada hakikatnya digunakan secara penuh untuk memikirkan sistem pembuatan strategi organisasinya. Keterlibatan ini disebabkan hal-hal sebagai berikut :

a. secara otoritas formal adalah satu-satunya yang diperbolehkan terlibat untuk memikirkan tindakan-tindakan yang penting atau yang baru dalam orgnisasinya.

b. Sebagai pusat informasi, atasan dapat memberikan jaminan atas keputusan yang terbaik, yang mencerminkan pengetahuan yang terbaru dan nilai-nilai organisasi.

c. Keputusan-keputusan yang strategis akan lebih mudah diambil secara terpadu dengan adanya satu orang yang dapat melakukan kontrol atas semuanya. 
Peranan menurut Katz da Kahn (dalam Miftah Thoha 2002) adalah integrasi organisasi merupakan peleburan komponen peranan, norma dan nilai. Peranan adalah serangkaian perilaku yang diharapkan dilakukan oleh seseorang yang ditentukan olehkarakteristik pribadi seseorang tentang apa yang diharapkan orang lain kepadanya dan kemauannya untuk mentaati yangtelah ditetapkan pengharapan tadi. Disamping itu Soejono Soekanto (2008:24) berpendapat bahwa peranan adalah aspek dinamis dari kedudukan (status). Apabila seseorang melaksakan hak dan kewajibannya sesuai dengan kedudukannya, maka ia menjalankan suatu peran. Kemudian Soekanto membagi peranan mejadi tiga yakni sebagai berikut :

1. Peranan aktif

Adalah peranan yang diberikan oleh anggota kelompok karena kedudukannya didalam kelompok sebagai aktifitas kelompok seperti pengurus, pejabat atau lain sebagainya.

2. Peranan Partisipatif

Adalah peranan yang diberikan oleh anggota kelompok kepada kelompoknya yang memberikan sumbangan yang sangat berguna bagi kelompok itu sendiri.

3. Peran Pasif

Adalah sumbangan anggota kelompok yang bersifat pasif, dimana anggota kelompok menahan dari agar memberikan kesmpatan kepada fungsi-fungsi lain dalam kelompok sehingga berjalan dengan baik.

4. Manajemen Sumber Daya

Manusia Menurut Noe, Hollenbeck, danWirght (2011: 2), Sumber daya manusia merupakan proses pembentukan sistem manajemen untuk memastikan potensi yang dimiliki manusia dimanfaatkan secara aktif dam efisien untuk mencapai tujuan. Disisi lain, menurut Sutrisno (2011), manajemen Sumber Daya Manusia mempunyai defenisi sebagai suatu perencanaan, pengorganisasian, pengarahan dan pengawasan atasa pengadaan, pengembangan, kompensasi, pengintegrasian, pemeliharaan dan pemutusan hubungan kerja dengan maksud untuk mencapai tujuan organisasi. Mangkunegara (2013 :2) berpendapat, sumber daya manusia merupakan suatu perencanaan, pengorganisasian, pelaksanaan, dan pengawasan terhadap pengadaan, pengembangan, pemberian balas jasa, pengintegrasian, pemeliharaan dan pemisahan tenaga kerja dalam mencapai tujuan organisasi. Kemudian Hasibuan (2013) mendefinisikan manajemen sumber daya manusia 
adalah ilmu dan seni yang mengatur hubungan dan peranan tenaga kerja agar efektif dan efisien membantu terwujudnya tujuan perusahaan, karyawan dan masyarakat.

5. Kinerja

Menurut Sthepan Robin (dalam Pasalong, 2007 :176) kinerja, adalah hasil evaluasi terhadap pekerjaan yang dilakukan oleh karyawan dibandingkan kriteria yang telah ditetapkan sebelumnya. Tangkilisan ( 2005:178) mengatakan kinerja adalah suatu keadaaan yang berkaitan dengn keberhasilan organisasi dalam menjalankan misi yang dimilikinya yang dapat diukur dari produktifitas, kualitias layanan, responsivitas, responsibilitas, dan akuntabilitas.

Edy Sutrisno (2010: 170-172) dalam bukunya mengutip beberapa pengertian dari beberapa ahli, antara lain :

a. lawrer dan Porter (1967) mendefinisikan kinerja sebagai kesuksesan seseorang dalam melaksanakan tugas.

b. Prawirosentono (1999) mengemungkakan kinerja adalah hasil kerja yang dicapai seseorang, sekelompok orang dalam organisasi, sesuai dengan wewenang dan tanggung jawab masing-masing dalam rangka mencapai tujuan organisasi bersangkutan secara legal, tidak melanggar hukum dan sesuai dengan moral maupun etika.

c. Minner (1990) kinerja adalah bagian seseorang diharapkan dapat berfungsi dan berprilaku sesuai dengan tugas yang telah diberikan.

d. Irrianto (2001) mendefiniskan kinerja karyawan adalah prestasi yang diperoleh seseorang dalam melakukan tugas.

e. Cormik \& Tiffin ((1980), kinerja adalah kuantitas, dan waktu yang digunakan dalam menjalankan tugas, waktu kerja adalah jumlah absen, keterlambatan dan lamanya bekerja.

\section{Pengertian Sekretariat Dewan Perwakilan Rakyat Daerah}

Sercara harfiah sekretariat adalah organisasi yang tugas pokoknya adalah melaksakan berbagai kerja ketatausahaan. Namun menurut Websteris third new international dictionary (1982) sekretariat adalah pertama, antar seorang sekretaris dan kedua, suatu kelompok pekerja sekretaris. Kemudian Moekijat juga memberikan pengertian tentang sekretariat yakni sebagai berikut :

a. Pada mulanya sekretariat sekedar merupakan tempat seorang sekretaris bertugas. 
b. Setelah mengalami perkembangan sekretariat merupakan suatu orgaisasi tempat sekretaris melakukan tugas dalam bidang :

- tata keterangan

- tata warkat

- tata usaha

c. Pada akhirnya sekretariat adalah organisasi tempat sekretaris beserta pembantunya melakukan rangkaian kegiatan penataan terhadap pekerjaan administrasi .

Dari defenisi kesekretariatan, maka kesekretariatan mencakup 3 (tiga) maksud yakni sebagai berikut :

1. kantor atau tempat kerja seorang sekretaris

2. kelompok sekretaris atau pegawai yang tugas pokoknya melakukan kegiatan tata usaha

3. bagian dari suatu organisasi yang melakukan kegiatan ketatausahaan untuk menunjang tercapainya tujuan organisasi

\section{Dewan Perwakilan Rakyat Daerah}

Pasal 1 ayat (4) Undang-undang Nomor 23 Tahun 2014 tentang Pemerintahan Daerah menyebutkan bahwa pengertian Dewan Perwakilan Rakyat Daerah yang selanjutnya disebut DPRD adalah lembaga perwakilan rakyat daerah sebagai unsur penyelenggaraan pemerintahan daerah. Miriam Budiardjo menyebutkan DPRD adalah lembaga legislative atau membuat peraturan, peraturan perundang-undangan yang dibuat mencerminkan kebijakankebijkan itu. DPRD dapat dikatakan merupakan badan yang mmebuat keputusan yang menyangkut kepentingan umum. Kemudian Fuad (dalam Jurnal Administrasi Negara 2000:24) mengartikan DPRD adalah institusi yang menjadi tumpuan untuk memperjuangkan kepentingan masyarakat daerah.

Berdasarkan pengertian tersebut dapat disimpulkan bahwa DPRD merupakan lembaga perwakilan rakyat yang berada didaerah dan sebagai salah satu unsur penyelenggara pemerintahan daerah yang bertugas membuat peraturan daerah dan menampung aspirasi masyarakat daerah yang diwakilinya.

\section{Fungsi-Fungsi DPRD}

Dewan perwakilan rakyat adalah lembaga perwakilan rakyat daerah sebagai unsur penyelenggaraan pemerintahan daerah. Secara umum peran ini diwujudkan dalam tiga fungsi, yaitu :

1. Fungsi Legislasi : adalah fungsi untuk membuat peraturan daerah bersama kepala daerah yang dalam hal ini adalah Bupati 
2. Fungsi Anggaran :fungsi yang dilaksanakan untuk membahas dan memberikan pertimbangan dan memberikan persetujuan rancangan Anggara Pendapatan Belanja Daerah (APBD) yang diajukan oleh Bupati.

3. Fungsi Pengawasan : yakni adalah fungsi yang dilakukan melalui pengwasan atas pelaksanaan Undang-undang, peraturan daerah dan APBD.

2. Tugas dan Wewenang DPRD berikut;

Adapun yang menjadi tugas DPRD kabupaten/kota secara umum adalah sebagai

a. Membentuk Peraturan Daerah Kabupaten/kota bersama Bupati/Walikota

b. Membahas dan memberikan persetujuan rancangan peraturan daerah mengenai anggaran pendapatan dan belanja daerah kabupaten/kota yang diajukan Bupati/Walikota.

c. Melaksankan pengawasan terhadap pelakanaan peraturan daerah dan anggaran pendapatan dan belanja daerah kabupaten/kota

d. Mengusulkan pengangkatan dan pemberhentian bupati/walikota dan/atau wakil bupati/wakil walikota kepada Menteri Dalam Negeri melalui gubernur untuk mendapatkan pengesahan pengangkatan dan/atau pemeberhentian.

e. Memilih wakil buoati/wakil walikota dalam hal terjadi kekosongan jabatan wakil buati/wakil wali kota

f. Memberikan pendapat atau pertimbangan kepada pemerintah daerah kabupaten/kota terhadap rencana perjanjian internasional di daerah.

g. Memberikanpersetujuan terhadap rencana kerja sama internasional yang dilakukan pemerintah daerah kabupaten/kota

h. Meminta laporan keterangan pertanggugjawaban bupati/walikota dalam penyelenggaraan pemerintahan daerah kabupaten/kota

i. Memberikan persetujuan terhadap rencana kerja sama dengan daerah lain atau dengan pihak ketiga yang membebani masyarakat dan daerah

j. Mengupayakan terlaksananyakewajiban daerah sesuai dengan peraturan perundang-undangan

k. Melaksanakan wewenang dan tugas lain yang diatur dalam ketentutan peraturan perundang-undangan. 


\section{METODELOGI}

Desain yang digunakan dalam penelitian ini adalah penelitian deskriptif dengan pendekatan kuantitatif. Deskriptif adalah proses pemecahan masalah yang diselidiki dengan melukiskan keadaan subjek dan objek penelitian pada saat sekarang berdasarkan fakta-fakta yang tampak atau bagaimana adanya. Pada umumnya penelitian deskriptif merupakan penelitian yang non hipotesis sehingga dalam rangka penelitiannya bahkan tidak perlu merumuskan hipotesisnya. Metode penelitian deskriptif adalah metode yang digunakan untuk dapat menggambarkan keselurhan objek penelitian secara akurat.

Menurut Sugiyono (2009:8), kuantitatif adalah penelitian berdasarkan pada data yang dapat dihitung untuk menghasilkan panaksiran yang kokoh dengan menggunakan rumus matematis.

\section{PEMBAHASAN}

Untuk menjawab rumusan masalah penelitian ini yakni bagaimana peranan sekretariat dewan perwakilan rakyat daerah Kabupaten Kuantan Singingi dan sesuai dengan metodologi yang digunakan dalam penelitian ini yang juga bertujuan untuk mengetahui seberapa besar peranan sekretariat DPRD dalam menunjang kinerja anggota Dewan Perwakilan Rakyat Daerah (DPRD) dalam menjalankan tugas dan fungsinya. Maka dari itu dalam hal ini peranan sekretariat didefinisikan secara konsepsional sebagai aspek yang dinamis sehubungan dengan pelaksanaan tugas dan fungsinya dalam memberikan pelayanan administrasi terhadap anggota DPRD Kabupaten Kuantan Singingi yang meliputi administrasi kesekretariatan, administrasi keuangan, penyediaan dan pengkoordinasian tenaga ahli yang diperlukan anggota DPRD, dan pelayanan administrasi lainnya untuk mendukung tugas dan fungsi DPRD.

Untuk itu perlu penulis uraikan terlebih dahulu tugas dan fungsi DPRD itu sendiriyakni :

\section{Legislasi}

Dalam arti luas legislasi merupakan proses dan produk pembuatan undang-undang dan regulsi. Legislasi dalam arti luas termasuk pula didalamnya adala pembentukan peraturan pemerintah dan praturan-peraturan lainnya yang mendpat delegasian kewenangan dari undang-undang. 


\section{Anggaran (Budgeting)}

Hal ini adalah fungsi DPRD bersama- sama pemerintah daerah untuk menyusun dan menetapkan anggaran pendapatan dan belanja daerah.

\section{Pengawasan}

Merupakan fungsi yang mentapkan apa yang telah dicapai, mengevaluasi. Pengawasan juga dapat dikatakan penegndalian dan pemeriksaan kinerja pemerintah dalam melaksanakan otonomi daerah dan strategi pengelolaan kekakyaan daerah untuk meningkatkan kinerja pemerintah daerah.

\section{Peranan Aktif}

Peran Aktif merupakan keterlibatan pegawai secara langsung dalam kegiatan yang kesekretariatan dewan perwakilan rakyat untuk berfikir, berinteraksi, bebrbuat dan mencoba, menemukan sebuah konsep dan mengahsilkan kerja yang menunjang kinerja anggota DPRD dalam nejalankan tugas dan fungsinya selaku wakil rakyat.Berikut tanggapan respon terhadap pernyataa peran aktif yang diberikan sekretarian DPRD guna menunjang kinerja DPRD dalam menjalankan tugas dan fungsinya.

Tabel 1. Rekapitulasi Peran Aktif

\begin{tabular}{|c|c|c|c|c|c|c|c|c|}
\hline \multirow{2}{*}{ No } & \multirow{2}{*}{ Indikator } & \multicolumn{5}{|c|}{ Kategor } & \multirow{2}{*}{$\begin{array}{l}\text { Jum } \\
\text {-lah }\end{array}$} & \multirow{2}{*}{$\begin{array}{l}\text { Rata- } \\
\text { rata }\end{array}$} \\
\hline & & SS & $\mathbf{S}$ & $\mathbf{R R}$ & TS & TSS & & \\
\hline 1. & $\begin{array}{l}\text { Berperan dalam pelaksanaan } \\
\text { administrasi kesekretariatan dan } \\
\text { keuangan secara baik }\end{array}$ & 1 & 32 & 2 & 0 & 0 & 35 & 3,97 \\
\hline 2. & $\begin{array}{l}\text { Berperan dalam memfasilitasi anggota } \\
\text { DPRD dalam pelaksanaan fungsi } \\
\text { legislasi seperti rapat, siding paripurana } \\
\text { dsbnya. }\end{array}$ & 4 & 26 & 4 & 1 & 0 & 35 & 3,94 \\
\hline 3. & $\begin{array}{l}\text { Berperan dalam membantu anggota } \\
\text { DPRD dalam pelaksanaan fungsi } \\
\text { Budgeting }\end{array}$ & 2 & 32 & 1 & 0 & 0 & 35 & 4,02 \\
\hline 4 & $\begin{array}{l}\text { Berperan dalam membantu anggota } \\
\text { DPRD dalam pelaksanaan fungsi } \\
\text { Pengawasan }\end{array}$ & 2 & 30 & 2 & 2 & 0 & 35 & 4 \\
\hline & Jumlah & 9 & 120 & 8 & 3 & 0 & 140 & \multirow{4}{*}{3,98} \\
\hline & Jumlah Responden & 2 & 30 & 2 & 1 & 0 & 35 & \\
\hline & Bobot & 10 & 120 & 6 & 2 & 0 & 130 & \\
\hline & Persentase $(\%)$ & 6 & 86 & 5 & 3 & 0 & 100 & \\
\hline
\end{tabular}

Sumber: Data Olahan, 2018

Beradasarkan tabel diatas dapat disimpulkan bahwa sekeretariat DRPD secara gari besar berperan aktif dalam menujang kinerja DPRD dalam menjalakan tugas dan fungsinya. 
Meskipun masih terdapat beberapa tanggapan responden yang menilai sekretariat kurang memiliki peranan yang belum spenuhnya menunjang kinerja anggota DPRD.

\section{Peranan Partisipatif}

Partisipasi adalah suatu keterlibatan mental dan emosional seseorang kepada pencapaian tujuan dan ikut bertanggungjawab didalamnya. Partisipasi adalah sebuah gejala demokrasi dimana seseorag diikutsertakan dalam suatu perencanaan serta dalam pelaksanaan dan ikut juga memikul tanggungjawab sesuai dengan tingkat kematangan dan tingkat kewajibanya. Dalam hal ini partisipasi yang dimaksud adalah partisipasi buah pikiran yang memunculkan ide, pemikiran atau buah pikiran yang konstruktif, baik untuk menyusun program maupun memperlancar pelaksanaan program dan juga mewujudkannya dengan memberikan pengalaman dan pengetahuan guna mengembangkan kegiatan yang diikuti.

Berikut tanggapan respon terhadap pernyataan peran partisipatif yang diberikan sekretariatan DPRD guna menunjang kinerja DPRD dalam menjalankan tugas dan fungsinya.

Tabel 2. Rekapitulasi Peran Patisipatif

\begin{tabular}{|c|c|c|c|c|c|c|c|c|}
\hline \multirow[b]{2}{*}{ No } & \multirow[b]{2}{*}{ Indikator } & \multicolumn{5}{|c|}{ Kategor } & \multirow{2}{*}{$\begin{array}{l}\text { Jum- } \\
\text { lah }\end{array}$} & \multirow{2}{*}{$\begin{array}{l}\text { Rata- } \\
\text { Rata }\end{array}$} \\
\hline & & SS & $\mathbf{S}$ & $\mathbf{R R}$ & TS & TSS & & \\
\hline 1. & $\begin{array}{l}\text { Berperan dalam pekerjaan dan } \\
\text { betanggungjawab secara moral maupun } \\
\text { secara professional. }\end{array}$ & 3 & 23 & 7 & 2 & 0 & 35 & 3,77 \\
\hline 2. & $\begin{array}{l}\text { Berperan dalam melakukan pekerjaan } \\
\text { dalam upaya mencapai tujuan organisasi }\end{array}$ & 10 & 21 & 3 & 1 & 0 & 35 & 4,14 \\
\hline 3. & $\begin{array}{l}\text { Memiliki kedisipilinan dalam } \\
\text { melaksanakan tugas-tugas } \\
\text { kesekretariatan }\end{array}$ & 0 & 13 & 14 & 8 & 0 & 35 & 3,14 \\
\hline 4 & $\begin{array}{l}\text { Memiliki sumbangan pemikiran, ide } \\
\text { dalam melakukan tugas kesekretariatan } \\
\text { guna menunjang anggta DPRD dalam } \\
\text { menjalankan tkaugas dan fungsinya }\end{array}$ & 4 & 26 & 4 & 1 & 0 & 35 & 3,94 \\
\hline & Jumlah & 17 & 83 & 28 & 12 & 0 & 140 & \multirow{4}{*}{3,74} \\
\hline & Jumlah Responden & 4 & 21 & 7 & 3 & 0 & 35 & \\
\hline & Bobot & 20 & 84 & 21 & 6 & 0 & 131 & \\
\hline & Persentase $(\%)$ & 11 & 60 & 20 & 9 & 0 & 100 & \\
\hline
\end{tabular}

Sumber: Data Olahan 2018

Berdasarkan tabel diatas dapat penulis simpulkan bahwa tingkat partisipatif pegawai sekretariat dewan perwakilan rakyat daerah masih bisa dikategorikan baik, meskipun terdapat masih terdapat penilaian yang belum memuaskan terhadap kinerja yang diberikan pegawai sekretariat DPRD dalam menjalankan tugas dan fungsinya baik itu dalam administrasi kesekretariatan, administrasi keuangan maupun dalam hal risalah. 


\section{Pranan Antar Pribadi}

Peranan antar pribadi adalah peranan orang dan kewajiban lain, yang bersifat seremonial dan simbolis. Peran ini meliputi figure sebagai anak buah, pemimpin dan penghubung. Berikut tanggapan responden terhadap pernyataan peran antar pribadi yang diberikan sekretariatan DPRD guna menunjang kinerja DPRD dalam menjalankan tugas dan fungsinya.

Tabel 3. Rekapitulasi Peran Antar Pribadi

\begin{tabular}{|c|c|c|c|c|c|c|c|c|}
\hline \multirow[b]{2}{*}{ No } & \multirow[b]{2}{*}{ Indikator } & \multicolumn{5}{|c|}{ Kategori } & \multirow{2}{*}{$\begin{array}{l}\text { Jum } \\
\text {-lah }\end{array}$} & \multirow{2}{*}{$\begin{array}{l}\text { Rata- } \\
\text { rata }\end{array}$} \\
\hline & & SS & $\mathbf{S}$ & $\mathbf{R R}$ & TS & TSS & & \\
\hline 1. & $\begin{array}{l}\text { Memiliki sikap kepedulian tinggi } \\
\text { terhadap anggota DPRD guna } \\
\text { menunjang kinerja DPRD }\end{array}$ & 2 & 23 & 9 & 1 & 0 & 35 & 3,74 \\
\hline 2. & $\begin{array}{l}\text { Mampu Membina hubungan baik } \\
\text { dengan para anggota DPRD dalam } \\
\text { Konteks pribadi }\end{array}$ & 1 & 14 & 12 & 8 & 0 & 35 & 3,22 \\
\hline 3. & $\begin{array}{l}\text { Mampu membina hubungan baik } \\
\text { dengan para anggota DPRD dalam } \\
\text { kontek Hubungan Kerja }\end{array}$ & 9 & 25 & 1 & 0 & 0 & 35 & 4,22 \\
\hline 4 & $\begin{array}{l}\text { Mampu Memelihara empati dan } \\
\text { kerjasama dengan anggota DPRD } \\
\text { dalam menunjang kinerja anggota } \\
\text { DPRD }\end{array}$ & 3 & 24 & 7 & 1 & 0 & 35 & 3,82 \\
\hline & Jumlah & 15 & 86 & 29 & 10 & 0 & 140 & \multirow{4}{*}{3,75} \\
\hline & Jumlah Responden & 4 & 21 & 7 & 3 & 0 & 35 & \\
\hline & Bobot & 20 & 84 & 21 & 6 & 0 & 131 & \\
\hline & Persentase (\%) & 11 & 60 & 20 & 9 & 0 & 100 & \\
\hline
\end{tabular}

Sumber: Data Olahan 2018

Berdasarkan rekapitulasi tabel diatas maka dapatlah penulis simpulkan bahwa pegawai sekretariat DPRD memiliki hubungan yang baik dengan anggota DPRD maupun dengan sesama pegawai sekretariat DPRD itu sendiri. Hal ini terlihat dari hasil rekapitulasi kuesioner yang telah di sebarkan kepada seluruh anggota DPRD kabupaten Kuantan Singingi. Dengan baiknya hubungan antar pribadi tesebut tentunya akan sangat menunjang kinerja anggota DPRD, karena tentunya anggota DPRD tidak akan maksimal menjalankan tugas dan fungsinya sebagai wakil rakyat jika tidak didukung oleh sekretariat DPRD itu sendiri. 


\section{Peranan Berhubungan Dengan Informasi}

Peranan ini adalah perananan yang berkaitan dengan peran sebagai pemantau dan penyebar informasi, serta peranan sebagai juru bicara. Berikut tanggapan responden terhadap pernyataan peran yang berhubungan dengan informasi yang diberikan sekretariatan DPRD guna menunjang kinerja DPRD dalam menjalankan tugas dan fungsinya.

Tabel 4. Rekapitulasi Peranan Berhubungan dengan Informasi

\begin{tabular}{|c|c|c|c|c|c|c|c|c|}
\hline \multirow{2}{*}{ No } & \multirow{2}{*}{ Indikator } & \multicolumn{5}{|c|}{ Kategor } & \multirow{2}{*}{$\begin{array}{l}\text { Jum } \\
\text {-lah }\end{array}$} & \multirow{2}{*}{$\begin{array}{l}\text { Rata- } \\
\text { rata }\end{array}$} \\
\hline & & SS & $\mathbf{S}$ & $\mathbf{R R}$ & TS & TSS & & \\
\hline 1. & $\begin{array}{l}\text { Mampu berkomunikasi secara baik } \\
\text { dengan anggota DPRD dalam } \\
\text { menyampaikan informasi yang } \\
\text { berkaitan dengan pelaksanaan } \\
\text { fungsi DPRD }\end{array}$ & 12 & 22 & 1 & 1 & 0 & 35 & 4,37 \\
\hline 2. & $\begin{array}{l}\text { Mampu menyebarkan pesan yang } \\
\text { bersifat dua arah, atau } \\
\text { berkomunikasi timbal balik dengan } \\
\text { anggota DPRD dalam upaya } \\
\text { menunjang kinerja DPRD }\end{array}$ & 8 & 25 & 2 & 0 & 0 & 35 & 4,17 \\
\hline 3. & $\begin{array}{l}\text { Mampu membina hubungan baik } \\
\text { dengan para anggota DPRD dalam } \\
\text { kontek Hubungan Kerja }\end{array}$ & 9 & 25 & 1 & 0 & 0 & 35 & 4,22 \\
\hline 4 & $\begin{array}{l}\text { Mampu Memelihara empati dan } \\
\text { kerjasama dengan anggota DPRD } \\
\text { dalam menunjang kinerja anggota } \\
\text { DPRD }\end{array}$ & 3 & 24 & 7 & 1 & 0 & 35 & 3,82 \\
\hline & $\begin{array}{r}\text { Jumlah } \\
\end{array}$ & 32 & 101 & 11 & 10 & 0 & 140 & \\
\hline & Jumlah Responsen & 8 & 25 & 2 & 2 & 0 & 35 & \\
\hline & Bobot & 40 & 100 & 6 & 4 & 0 & 150 & 4,10 \\
\hline & Persentase & 20 & 70 & 5 & 5 & 0 & 100 & \\
\hline
\end{tabular}

Sumber: Data Olahan 2018

Rekapitulasi diatas menyatakan bahwa pegawai sekretariat DPRD mampu berperan secara baik dalam menyampaikan informasi-informasi yang menunjang kinerja DPRD Kabupaten Kuantan Singingi. Hal ini tentunya akan berdampak sangat positif bagi peningkatan kinerja DPRD dalam membuat kebijakan-kebijakan yang mengutamakan kepentingan masyarakat. 


\section{Peranan Pengambilan Keputusan}

Dalam hal peran pengambilan keputusan merupakan suatu peran yang bertindak sebagai pemecah masalah, pembagi sumber daya dan mampu melakukan perundingan. Berikut tanggapan responden terhadap pernyataan peranan pengambilan keputusan yang diberikan sekretariatan DPRD guna menunjang kinerja DPRD dalam menjalankan tugas dan fungsinya.

Tabel. 5 Rekapitulasi Peran Pengambilan Keputusan

\begin{tabular}{|c|c|c|c|c|c|c|c|c|}
\hline \multirow[b]{2}{*}{ No } & \multirow[b]{2}{*}{ Indikator } & \multicolumn{5}{|c|}{ Kategor } & \multirow{2}{*}{$\begin{array}{l}\text { Jum- } \\
\text { lah }\end{array}$} & \multirow{2}{*}{$\begin{array}{l}\text { Rata - } \\
\text { Rata }\end{array}$} \\
\hline & & SS & $\mathbf{S}$ & $\mathbf{R R}$ & TS & TSS & & \\
\hline 1. & $\begin{array}{l}\text { Mampu memecahkan masalah yang } \\
\text { terjadi yang berkaitan dengan } \\
\text { proses administrasi kesekretariatan } \\
\text { yang menghambat upaya } \\
\text { pelaksanaan fungsi DPRD }\end{array}$ & 12 & 22 & 1 & 1 & 0 & 35 & 4,37 \\
\hline 2. & $\begin{array}{l}\text { Mampu menempatkan Sumber daya } \\
\text { Manusia sesuai dengan bidang } \\
\text { kompetensi guna meningkatkan } \\
\text { kinerja pegawai. }\end{array}$ & 8 & 25 & 2 & 0 & 0 & 35 & 4,17 \\
\hline 3. & $\begin{array}{l}\text { Mampu melakukan perundingan } \\
\text { secara baik ketika terjadi perbedaan } \\
\text { pendapat atar individu }\end{array}$ & 9 & 25 & 1 & 0 & 0 & 35 & 4,22 \\
\hline 4 & $\begin{array}{l}\text { Mampu mengambil keputusan yang } \\
\text { tepat guna dalam persoalan } \\
\text { administrasi kesekretariatan, } \\
\text { administrasi keuangan, dan risalah. }\end{array}$ & 3 & 24 & 7 & 1 & 0 & 35 & 3,82 \\
\hline & Jumlah & 32 & 101 & 11 & 10 & 0 & 140 & \multirow{4}{*}{4,14} \\
\hline & Jumlah Respon & 8 & 25 & 2 & 2 & 0 & 35 & \\
\hline & Bobot & 40 & 100 & 6 & 4 & 0 & 150 & \\
\hline & Persentase $(\%)$ & 22 & 70 & 5 & 5 & 0 & 100 & \\
\hline
\end{tabular}

Sumber: Data Olahan 2018

Berdasarkan rekapitulasi diatas dapat disimpulkan bahwa sekretariat DPRD telah mampu melakukan pengambilan keputusan yang secara baik, guna menunjang kinerja anggota DPRD dalam melaksanakan tugas dan fungsinya secara baik. 
Tabel. 6. Rekafitulasi Peranan Sekretariat Dewan Perwakilan Rakyat Daerah (DPRD) Dalam Menunjang Kinerja Dewan Perwakilan Rakyat Daerah (DPRD) Kabupaten Kuantan Singingi dalam menjalankan tugas dan fungsinya.

\begin{tabular}{|c|c|c|c|c|c|c|c|c|}
\hline \multirow{2}{*}{ No } & \multirow{2}{*}{ Indikator } & \multicolumn{5}{|c|}{ Kategori } & \multirow{2}{*}{$\begin{array}{l}\text { Jum- } \\
\text { lah }\end{array}$} & \multirow{2}{*}{ Rata - rata } \\
\hline & & SS & $\mathbf{S}$ & $\mathbf{R R}$ & TS & TSS & & \\
\hline 1. & Peranan Aktif & 2 & 30 & 2 & 1 & 0 & 35 & \multirow{3}{*}{3,98} \\
\hline \multicolumn{2}{|c|}{ Persentase (\%) } & 6 & 86 & 5 & 3 & 0 & 100 & \\
\hline \multicolumn{2}{|c|}{ Total Bobot } & 10 & 120 & 6 & 2 & 0 & 130 & \\
\hline 2. & Peran Partisipasi & 4 & 21 & 7 & 3 & 0 & 35 & \multirow{3}{*}{3,74} \\
\hline \multicolumn{2}{|c|}{ Persentase (\%) } & 11 & 60 & 20 & 9 & 0 & 100 & \\
\hline \multicolumn{2}{|c|}{ Total Bobot } & 20 & 84 & 21 & 6 & 0 & 140 & \\
\hline 3. & Peran Antar Pribadi & 4 & 21 & 7 & 3 & 0 & 35 & \multirow{3}{*}{3,75} \\
\hline \multicolumn{2}{|c|}{ Persentase $(\%)$} & 11 & 60 & 20 & 9 & 0 & 100 & \\
\hline \multicolumn{2}{|c|}{ Total Bobot } & 20 & 84 & 21 & 6 & 0 & 131 & \\
\hline 4. & $\begin{array}{l}\text { Peran Berhubungan } \\
\text { dengan Informasi }\end{array}$ & 8 & 25 & 2 & 2 & 0 & 35 & \multirow{3}{*}{4,16} \\
\hline \multicolumn{2}{|c|}{ Persentase $(\%)$} & 20 & 70 & 5 & 5 & 0 & 100 & \\
\hline \multicolumn{2}{|c|}{ Total Bobot } & 40 & 100 & 6 & 4 & 0 & 150 & \\
\hline 5. & $\begin{array}{l}\text { Peran Pengambilan } \\
\text { Keputusan }\end{array}$ & 8 & 25 & 2 & 2 & 0 & 35 & \multirow{3}{*}{4,14} \\
\hline \multicolumn{2}{|c|}{ Persentase $(\%)$} & 20 & 70 & 5 & 5 & 0 & 100 & \\
\hline \multicolumn{2}{|c|}{ Total Bobot } & 40 & 100 & 6 & 4 & 0 & 150 & \\
\hline \multicolumn{2}{|c|}{ Jumlah } & 31 & 122 & 20 & 11 & $\mathbf{0}$ & 184 & \multirow{4}{*}{3,95} \\
\hline \multicolumn{2}{|c|}{ Jumlah Responden } & 6 & 23 & 4 & 2 & $\mathbf{0}$ & 35 & \\
\hline \multicolumn{2}{|c|}{ Bobot } & 30 & 92 & 12 & 4 & $\mathbf{0}$ & 138 & \\
\hline \multicolumn{2}{|c|}{ Persentase (\%) } & 17 & 66 & 11 & 6 & $\mathbf{0}$ & 100 & \\
\hline
\end{tabular}

\section{KESIMPULAN}

Berdasarkan hasil analyses yang telah penulis lakukan dapat disimpulkan mengenai peranan sekretariat Dewan Perwakilan Rakyat Daerah Kabupaten Kuantan Singingi adalah :

1. Peranan sekretariat DPRD kabupaten Kuantan Singingi dalam mendukung pelaksanaan fungsi DPRD sudah dilakukan secara efektif hal ini dapat dilihat dari pelaksanaan kegitan-kegiatan yang dilakukan anggota DPRD telah terealisasi secara baik.

2. Peranan Sekeratriat DPRD dalam menunjang kinerja DPRD dalam hal pelaksnaan fungsi DPRD salah satu nya legislasi juga telah bisa dikatakan dengan baik. Hal ini terlihat tanggapan anggota DPRD yang menyatakan secretariat sangat mendukung dengan terlaksananya rapat ataupun pleno yang berjalan secara baik setiap kali dilaksanakan. 
3. Faktor-faktor seperti hubungan antar pribadi, kompetensi Sumber daya yang ada juga dapat dikatan baik, hal ini dapat dilihat dari kemampuan secretariat DPRD dalam memberikan informasi dan juga mampu berkomunikasi dua arah atau timbale balik dengan anggota DPRD dalam upaya menunjang kinerja DPRD kabupaten kuantan singing.

\section{DAFTAR PUSTAKA}

Arikunto, S. (2006). Prosedur Penelitian, Suatu Pendekatan Praktek. Jakarta: Rineka Cipta.

H. A.W. Widjaja. (2006). Pembangunan Konerja dan Masalah Kepemimpinannya. Jakarta: Rajawali.

, (2005). Penyelenggaraan Otonomi di Indonesia, Jakarta: PT. Raja Grafindo Persada.

Edi, Suhardono. (1994). Teori Peran, Konsep, Derivasi dan Implikasinya. Jakarta : Gramedia Pustaka Utama.

Hasibuan, SP. Melayu. (2010). Manajemen Sumber Daya Manusia. Jakarta: Bumi Aksara.

Soekanto, Soerjono. (2009). Sosiologi Sebagai Pengantar. Jakarta : Edisi Baru Rajawali Pers.

Sarudayang, 2005.Babak Baru Sistem Pemerintahan Daerah. Jakarta: Kasta Hasta.

Sarwanto. (1996). Efektivitas Organisasi. Jakarta :Erlangga.

Thoha, Mifta. (2002). Pembinaan Organisasi:Proses Doagnosa dan Intervensi. Jakarta: Rajawali Grafindo Persada.

\& Siswanto. (2012). Pegantar Manajemen\& Kepemimpinan Dalam Manajemen. Jakarta.

A.W. Widjaja. (2006). Pembangunan Kinerja dan Masalah Kepemimpinannya. Jakarta: Rajawali.

Chandra dewi, Ayuningtyas. (2008). Faktor yang Mempengaruhi Produktivitas Kerja.

Sjahmien, Moefli. (2003). (Ed.), factor yang mempengaruhi produktivitas. (http://www.scribd.com/doc/56524013/15/Faktor YangMempengaruhiProduktivitas-Kerja, di akses pada tanggal 25 Februari 2017).

Hasibuan. Sp. Melayu. (2010). Manajeman Sumber Daya Manusia. Jakarta: Bumi Aksara. 
Laksana. (2008). Manajemen Pelayanan Prima. Jakarta: Penerbit Buku Kedokteran EGC.

Moenir. (2001). Standar Pelayanan Publik Pemerintah Daerah, Indonesia Quality Research Agency (IQR 